\title{
The Effect of Temperature on Drying Rate of Agro Food: Corn (Maize) and Ogbono (Irivingia Gabonnensis)
}

\author{
*Gumus R.H. and Ketebe E. \\ Department of Chemical and Petroleum Engineering, Niger Delta University, Wilberforce Island. P.M.B. 071 \\ Bayelsa State, Nigeria
}

\begin{abstract}
The storage of stable agro food such as corn and ogbono in developing countries like Nigeria is a great challenge due to high moisture content that causes deterioration at long period. However, dried agro food at certain temperatures could reduce this deterioration challenge and would extend storage life. In this study, the effect of temperature on drying rate and moisture content was carried out at $110^{\circ} \mathrm{C}, 120^{\circ} \mathrm{C}$ and $130^{\circ} \mathrm{C}$ on corn and ogbono, with the initial moisture content of $(0.28 \mathrm{~g})$. The moisture content decreased as time increases but tend to be constant with further increase in time. The minimum moisture content retained were $(0.12 \mathrm{~g}, 0.11 \mathrm{~g}$, and $0.1 \mathrm{~g})$ for corn and $(0.85 \mathrm{~g}, 0.83 \mathrm{~g}$ and $0.8 \mathrm{~g})$ for ogbono at $110^{\circ} \mathrm{C}, 120^{\circ} \mathrm{C}$ and $130^{\circ} \mathrm{C}$ respectively. The drying rate at $130^{\circ} \mathrm{C}$ was higher compared to $120^{\circ} \mathrm{C}$ and $110^{\circ} \mathrm{C}$ but there was shrinkage and undesirable colour change observed. The characterization of the dried product using proximate analysis showed that drying at $110^{\circ} \mathrm{C}$ is more suitable for consumption both for the young and the elderly, with lower level of carbohydrate, corn (76.80) and ogbono (83.63) while protein, fiber and lipid levels of corn (9.94), (2.80), 3.78) and ogbono (5.40), (2.40), (2.17) respectively. Due to the favorable condition at $110^{\circ} \mathrm{C}$, mineral analysis was also carried out, which showed trace elements of ogbono $\mathrm{Ca}(0.34), \mathrm{Mg}(0.081), \mathrm{Na}(0.025), \mathrm{K}(0.25), \mathrm{P}(0.15), \mathrm{Mn}(0.068)$ and $\mathrm{Fe}(0.010)$ and corn; $\mathrm{Ca}(0.180), \mathrm{Mg}(0.065), \mathrm{Na}(0.017),(0.2), \mathrm{P}(0.28), \mathrm{Mn}(0.068)$ and $\mathrm{Fe}(0.002)$.
\end{abstract}

\section{I.INTRODUCTION}

Drying is perhaps the oldest, most common and most diverse of chemical engineering unit operations in the preservation of agricultural food materials or products [1]. It is the process moisture (water) removal from substances due to simultaneous heat and mass transfer [2]. The mechanism of drying process consist of the transport of (mass) moisture from the interior of the solid to the surface, the vaporization of liquid at the surface (diffusion) and the transport of the vapor into gas phase [3]. The drying operation reduces the moisture content of solids to a condition favorable for safe storage without deteriorations. The most significance reason for the popularity of dried products is that in dehydrated foods, microorganisms practically do not grow due to the presence of a minimum amount of water and thus they are immune to enzymatic reactions that could provoke alterations or spoilage in the food $[4,5]$. The best way of maintaining the nutritional value of most agricultural product or fruits is by keeping the products fresh. The challenges are mostly the storage methods, that requires low temperature which are difficult to maintain in the developing countries $[6,7]$. Drying is a complex operation involving transient transfer of heat and, mass along with several rate processes, such as physical or chemical transformations, which, in turn may cause changes in product quality as well as the mechanisms of heat and mass transfer [8]. Many of these changes are functions of moisture content, temperature and time. Therefore, knowledge of the minimum moisture content and temperature of the drying time is needed in order to maintain its stability during storage, evaluate its final quality and stimulate the drying process. Since most foods or other heat-sensitive biomaterials are damaged at the saturation temperature of super-heated steam corresponding to the atmospheric or higher pressures, one possible way to alleviate the above- mentioned problem is to operate the dryer at reduced pressure.

Ogbono is a major part of people's food, in most part of Nigeria, the Niger delta region, a very suitable region for this economic (ogbono) tree. Although the seed fruit is seasonal, this economic tree would not be affected by even great flood. The ogbono seed is a tropical fruit known as bush mango or wild mango. The subtly aromatic nuts are conventionally open sun dried for preservation, and are sold whole or in powder form. The high content of mucilage (a thick, gluey substance produce by polar glycol protein) enables it to be used as thickening agents for dishes such as ogbono soup. The nuts may also be pressed for vegetable oil. It is rich with protein, calcium, iron, fiber, carbohydrate, fatty acid and the fruit seed extract is regarded as the natural and safe diet supplement. The dehydration process improves stability since it reduces considerably the liquid and microbiological activity of the material and minimizes the physical and chemical changes during storage [4]. Therefore, the loss of product could be decreased in addition to making them available throughout the year. Simultaneous transfer of mass from the surface and heat to the surface and into the material, hydrodynamics of the movement of particle in the dryer, mechanism of moisture transport within the solid material and shrinkage are some of the problems associated with drying of ogbono. A higher quality product would have a desirable 
colour, texture, nutritional value and flavor as well as shape and certain functional properties such as rehydration and porosity. If these factors could not be achieved to an acceptable level then the dried product will be unappealing to the consumer. Also, corn is a popular daily product that is extensively consumed due to its nutritional value. In the food industry, the dehydrated corn has a great importance. It is prepared either; boiled, roasted, dehydrated and sterilized or in powdered form which have a considerable commercial success in many countries [3]. A dried corn kernel in a thin layer, using a high airflow rate has been studied [9]. They found that the solution of the diffusion equation for a sphere with an initial uniform moisture content distribution described satisfactorily the relationship between the kernel moisture and the drying time for shelled corn [9]. The effects of drying in a forced - convection oven on the properties of wheat germ proteins has also been studied [9]. They correlated the germination of the drying time using a first germ-drying a first -order kinetic model, estimating a constant germ- drying temperature, directly by differential scanning calorimeter. The thin-layer drying of grains has received different treatments in literature. Many research groups reported that it is the moisture diffusion that controls the drying of grain, at moderate kernel temperatures [8]. With the assumption of a spherical body with uniform diffusivity, various investigators found that the analytical solution to the diffusion equation reproduce the general form of the experimental drying curves of various cereal grains [3].

A sub -atmospheric pressure super heated steam drying of shrimps, banana, apple and cassava slices both experimentally and theoretically have been reported [10]. A semi-empirical mathematics model was developed based on a theoretical drying mechanism, which assumes that the water removal is carried out by evaporation in a moving boundary allowing the vapor to flow through the dry layer as drying proceeds.

Several researches on drying of vegetables and fruits have been reported in literature. However, little or/no information is available on the effect of temperature on drying rate and nutritional value of ogbono. Therefore, the purpose of this work is to experimentally study the effect of temperature on drying rate as well as the nutritional value of ogbono and corn.

\section{MATERIALS AND METHOD}

Fresh Corn, Fresh Ogbono, IR-30 Moisture Analyzer, Pan, Crucible, Oven, Furnace, Kjeldahl flask, $5 \mathrm{ml}$ conc. $\mathrm{H}_{2} \mathrm{SO}_{4}, \mathrm{NaOH}$, Filter paper, Beaker.

\subsection{Sample preparation and Moisture content determination}

The fresh harvested corn and bush mango were purchased from local market in Wilberforce Island, .Bayelsa State. Nigeria). The obtained corn was washed, dehusked while the bush mango was split into two equal halves to obtain the seed known as ogbono, with initial weight of $0.28 \mathrm{~g}$ and $1.28 \mathrm{~g}$ respectively. The moisture analyzer determines the weight of the samples at the set temperature for a period of 95 minutes and the change in weight of the samples gave the moisture different 5 minutes interval. The change of mass during drying was continuously measured. The set temperatures for the experiment were $110^{\circ} \mathrm{C}, 120^{\circ} \mathrm{C}$ and $130^{\circ} \mathrm{C}$ respectively for a period of 95 minutes. The loss per gram continuously decreases until it becomes constant for a long time (reduced moisture). As soon as the preset time is up, the moisture analyzer will automatically shut off.

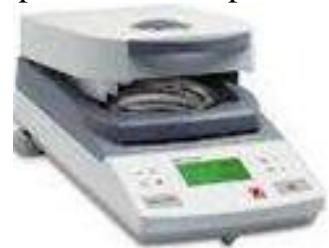

Figure1. IR-30 Moisture Analyzer.

For moisture determination, the amount of moisture in the sample is in \% or grams. Theoretically, the weight of the drying sample can be measured as a function of time from wet product to bone dry product (achieved minimum moisture content), which also can be used to check if the experimental data are correct

$$
\begin{aligned}
& \text { moisture content ratio of corn }=\frac{\text { Initial Weight-Final Weight }}{\text { Initial Weight }} \times 100 \\
& =\frac{0.28-0.1}{0.28} \times 100 \\
& =64 \% \\
& \text { grams }=\frac{64}{100}=0.64 \mathrm{~g} \\
& \text { wet product }=0.28 \times 0.64=0.179 \mathrm{~g} \\
& \text { bone dry product }=0.28 \times[1-0.64] \\
& =0.28 \times 0.36 \\
& =0.1008 \mathrm{~g}
\end{aligned}
$$


moisture content ratio of ogbono $=\frac{\text { Initial Weight }- \text { Final Weight }}{\text { Initial Weight }} \times 100$

$$
\begin{aligned}
& \quad \frac{1.28-0.8}{1.28} \times 100=37.5 \% \\
& \text { grams }=\frac{37.5}{100}=0.375 \mathrm{~g} \\
& \text { wet basis product }=1.28 \times[0.375]=0.48 \mathrm{~g}
\end{aligned}
$$

bone dry basis product $=1.28 \times[1-0.375]$

$$
\begin{aligned}
& =1.28 \times 0.625 \\
& =0.8 g .
\end{aligned}
$$

The result for the bone dry product for minimum moisture content is the same as that of the experimented value. Critical moisture content is moisture content at which drying rate first begins to drop (under constant drying conditions).

\subsection{Drying Rate Determination}

Drying rate was determined, using the moisture content data with time. e.g for Ogbono at $110^{\circ} \mathrm{C}$; Using this formular $=g / g . \min$

$$
\begin{gathered}
=[1.28 / 1.2] \mathrm{g} \mathrm{min} \\
=0.08 \mathrm{~g} \text { min } .
\end{gathered}
$$

\subsection{Proximate Analysis}

The analysis was used to obtain the nutritional values in comparing at different temperatures of corn and ogbono. For example to get $\%$ ash content

$\%$ ash content $=\frac{\text { Weight of as } h}{\text { weight of oven }- \text { dried sample }} \times 100$

\section{RESULTS AND DISCUSSION}

The experimental data obtained were used to calculate moisture content and drying rate at varying temperatures of $110^{\circ} \mathrm{C}, 120^{\circ} \mathrm{C}$ and $130^{\circ} \mathrm{C}$. The moisture content data and drying rate are presented in Tables 1 , 2,3 , and 4 respectively.

\subsection{MOISTURE CONTENT}

As drying proceeds, the rate at which moisture reduces was faster at $130^{\circ} \mathrm{C}$ as seen in the moisture content results, compared to the other two temperatures. The higher the temperature the faster the rate of moisture being removed (See Figures 1 and 2). The initial moisture content for all the temperatures considered

\begin{tabular}{|c|c|c|c|}
\hline Time (min) & $\begin{array}{l}\text { Moisture content }(\mathrm{g} / \mathrm{g} \\
\text { dry matter })\left(110^{\circ} \mathrm{C}\right)\end{array}$ & $\begin{array}{l}\text { Moisture content ( } \mathrm{g} / \mathrm{g} \text { dry matter) } \\
\left(120^{\circ} \mathrm{C}\right)\end{array}$ & $\begin{array}{l}\text { Moisture content }(\mathrm{g} / \\
\text { g dry matter })\left(130^{\circ} \mathrm{C}\right)\end{array}$ \\
\hline 0 & 0.28 & 0.28 & 0.28 \\
\hline 5 & 0.27 & 0.265 & 0.26 \\
\hline 10 & 0.25 & 0.245 & 0.24 \\
\hline 15 & 0.22 & 0.21 & 0.2 \\
\hline 20 & 0.2 & 0.193 & $0.1 \mathrm{~s}$ \\
\hline 25 & 0.18 & 0.176 & 0.16 \\
\hline 30 & 0.172 & 0.167 & 0.15 \\
\hline 35 & 0.166 & 0.15 & 0.14 \\
\hline 40 & 0.16 & 0.144 & 0.13 \\
\hline 45 & 0.154 & 0.139 & 0.12 \\
\hline 50 & 0.154 & 0.135 & 0.12 \\
\hline 55 & 0.154 & 0.135 & 0.12 \\
\hline 60 & 0.154 & 0.135 & 0.11 \\
\hline 65 & 0.148 & 0.135 & 0.11 \\
\hline 70 & 0.146 & 0.132 & 0.1 \\
\hline 75 & 0.14 & 0.12 & 0.1 \\
\hline 80 & 0.13 & 0.11 & 0.1 \\
\hline 85 & 0.12 & 0.11 & 0.1 \\
\hline 90 & 0.12 & 0.11 & 0.1 \\
\hline & & & \\
\hline 95 & 0.12 & 0.11 & 0.1 \\
\hline
\end{tabular}
was the same $(0.28 \mathrm{~g})$. The moisture content decreased as time increases but tend to be constant with further increase in time. At different temperatures the minimum moisture content retained were $(0.12 \mathrm{~g}, 0.11 \mathrm{~g}$, and 0.1 $\mathrm{g})$ for corn and $(0.85 \mathrm{~g}, 0.83 \mathrm{~g}$ and $0.8 \mathrm{~g})$ for ogbono at $110^{\circ} \mathrm{C}, 120^{\circ} \mathrm{C}$ and $130^{\circ} \mathrm{C}$ respectively. The lowest minimum moisture content of corn at $130^{\circ} \mathrm{C}$ was $(0.1 \mathrm{~g})$ among the temperatures studied which compared favorably with reports in literature $(0.1 \leq M \geq 0.2)$ [11]. However, the result for ogbono (minimum moisture content) was $0.8 \mathrm{~g}$ which is little/or not available in literature. 


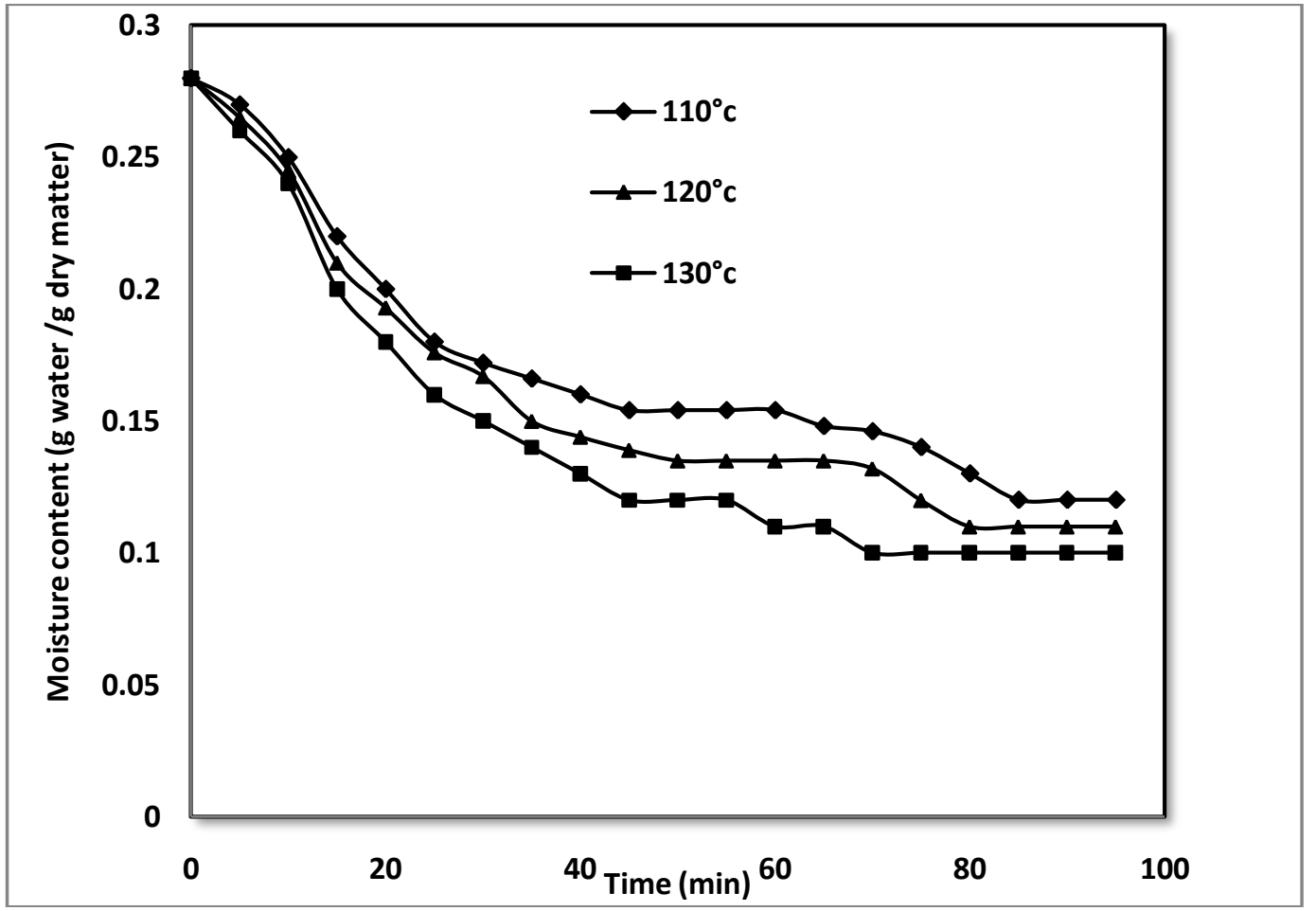

Figure 1. Moisture content versus time of corn at varying temperatures.

Table 2 Experimental values of moisture content of Ogbono at varying temperatures.

\begin{tabular}{|l|l|l|l|}
\hline Time $(\mathrm{min})$ & $\begin{array}{l}\text { Moisture content }(\mathrm{g} / \mathrm{g} \\
\text { dry matter }\left(110^{\circ} \mathrm{C}\right)\end{array}$ & $\begin{array}{l}\text { Moisture content }(\mathrm{g} / \mathrm{g} \\
\text { dry matter })\left(120^{\circ} \mathrm{C}\right)\end{array}$ & $\begin{array}{l}\text { Moisture content } \\
(\mathrm{g} / \mathrm{g} \text { dry matter }) \\
\left(130^{\circ} \mathrm{C}\right)\end{array}$ \\
\hline 0 & 1.28 & 1.28 & 1.28 \\
\hline 5 & 1.2 & 1.19 & 1.18 \\
\hline 10 & 1.12 & 1.1 & 1.07 \\
\hline 15 & 1.04 & 1.01 & 0.96 \\
\hline 20 & 0.98 & 0.95 & 0.89 \\
\hline 25 & 0.93 & 0.9 & 0.85 \\
\hline 30 & 0.9 & 0.885 & 0.83 \\
\hline 35 & 0.89 & 0.86 & 0.81 \\
\hline 40 & 0.88 & 0.852 & 0.81 \\
\hline 45 & 0.87 & 0.846 & 0.81 \\
\hline 50 & 0.86 & 0.842 & 0.81 \\
\hline 55 & 0.855 & 0.84 & 0.81 \\
\hline 60 & 0.85 & 0.83 & 0.8 \\
\hline 65 & 0.85 & 0.83 & 0.8 \\
\hline 70 & 0.85 & 0.83 & 0.8 \\
\hline 75 & 0.85 & 0.83 & 0.8 \\
\hline 80 & 0.85 & 0.83 & 0.8 \\
\hline 85 & 0.85 & 0.83 & 0.8 \\
\hline 90 & 0.85 & 0.83 & 0.8 \\
\hline 95 & 0.85 & 0.83 & 0.8 \\
\hline & & & \\
\hline & & & \\
\hline
\end{tabular}




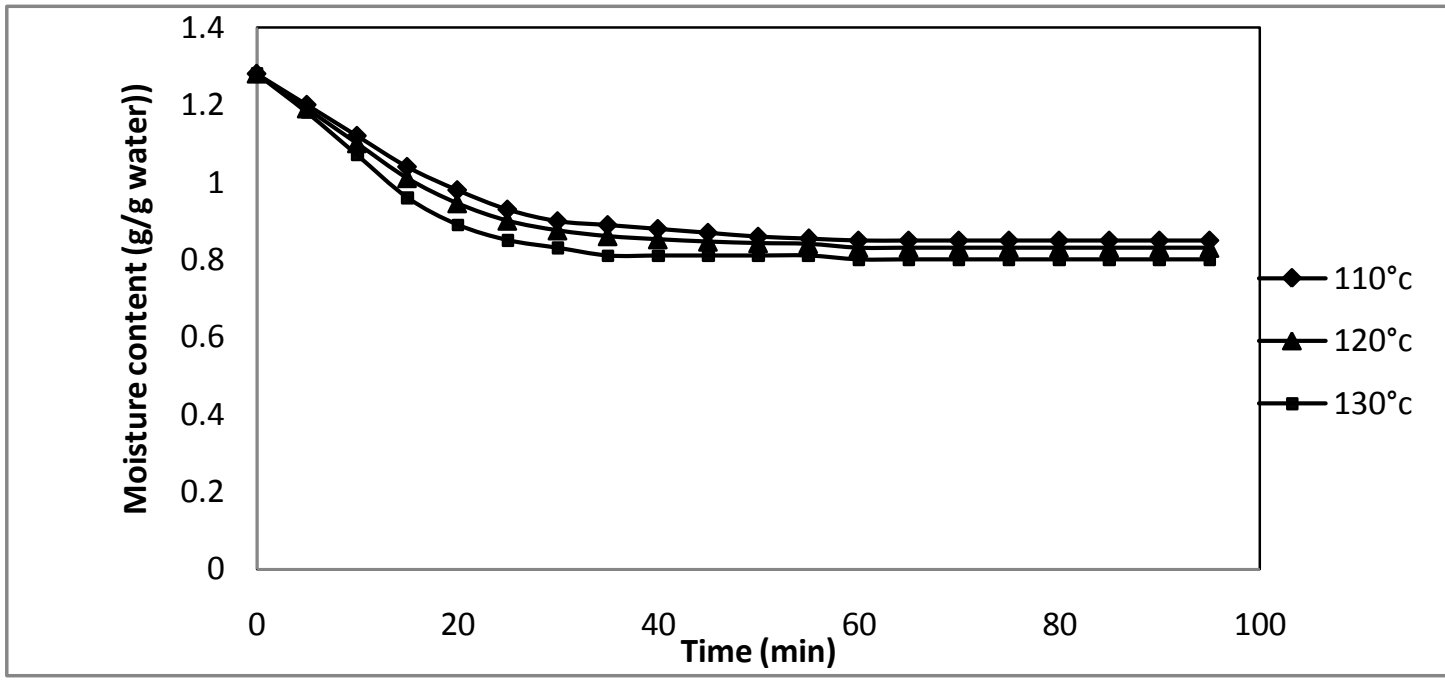

Figure 2 Moisture content versus time for ogbono at varying temperatures.

\subsection{DRYING RATE}

Figures 3 and 4 showed the drying rate for corn and ogbono at varying temperatures. For corn, initial drying rate after $5 \mathrm{~min}$ was $0.03 \mathrm{~g}, 0.035 \mathrm{~g}$ and $0.04 \mathrm{~g}$ at the various temperatures $110^{\circ} \mathrm{C}, 120^{\circ} \mathrm{C}$, and $130^{\circ} \mathrm{C}$. A warming period was observed from $0-5$ minutes after which a constant rate period started from 5-15 minutes at the varying temperatures. At 15 minutes which is the critical point, the rate of drying dropped gradually to 20 minutes. The drying rate remained constant again at $20-25$ minutes at $130^{\circ} \mathrm{C}$ and $120^{\circ} \mathrm{C}$. At $30-45$ minutes, a constant drying rate was observed again at $130^{\circ} \mathrm{C}$, and dropped at 45 minutes.

For the ogbono, the initial drying rate after 5 minutes, were $0.08 \mathrm{~g}, 0.09 \mathrm{~g}$ and $0.1 \mathrm{~g}$ at varying temperatures. A similar trend was observed for ogbono where a warming period was observed from $0-5$ minutes. This period is where sensible heat is transferred to the product and the contained moisture, with a slight change in moisture content. This period is the heating up of the product from the inlet condition to the process condition, which enables the subsequent processes to take place. All the drying air, is used to heat up the product to the drying temperature.

The constant rate period started from $5-15$ minutes at the varying temperatures. Once the grain is at the drying temperature, water starts to evaporate from the surface of the grain. During this period, all the heat from the drying air is used to evaporate the surface moisture and the amount of moisture removed from the grain is constant. It is therefore called the constant- rate period. A common occurrence is that the time scale of the constant rate period may determine and affect the rate of drying, in the next phase. At the critical point 15 minutes, the rate of drying dropped gradually. At $130^{\circ} \mathrm{C}$, it was observed that the drying rate remained constant again between $30-35$ minutes but at $110^{\circ} \mathrm{C}$ a constant rate was also observed between $35-50$ minutes. The falling rate is the period, during which the rate falls continuously with time [9]

Table 3 Experimental values of drying rate of corn at varying temperatures.

\begin{tabular}{|l|l|l|l|}
\hline (Time min $)$ & $\begin{array}{l}\text { Drying rate }(\mathrm{g} / \mathrm{g} / \\
\min )\left(110^{\circ} \mathrm{C}\right)\end{array}$ & $\begin{array}{l}\text { Drying rate }(\mathrm{g} / \mathrm{g} / \mathrm{min}) \\
\left(120^{\circ} \mathrm{C}\right)\end{array}$ & $\begin{array}{l}\text { Drying rate }(\mathrm{g} / \mathrm{g} / \mathrm{min}) \\
\left(130^{\circ} \mathrm{C}\right)\end{array}$ \\
\hline 0 & 0 & 0 & 0 \\
\hline 5 & 0.03 & 0.035 & 0.04 \\
\hline 10 & 0.03 & 0.035 & 0.04 \\
\hline 15 & 0.03 & 0.035 & 0.04 \\
\hline 20 & 0.015 & 0.017 & 0.02 \\
\hline 25 & 0.01 & 0.017 & 0.02 \\
\hline 30 & 0.008 & 0.009 & 0.01 \\
\hline 35 & 0.006 & 0.007 & 0.01 \\
\hline 40 & 0.006 & 0.006 & 0.01 \\
\hline 45 & 0.004 & 0.005 & 0.01 \\
\hline 50 & 0 & 0.004 & 0 \\
\hline 55 & 0 & 0 & 0 \\
\hline 60 & 0 & 0 & 0 \\
\hline
\end{tabular}




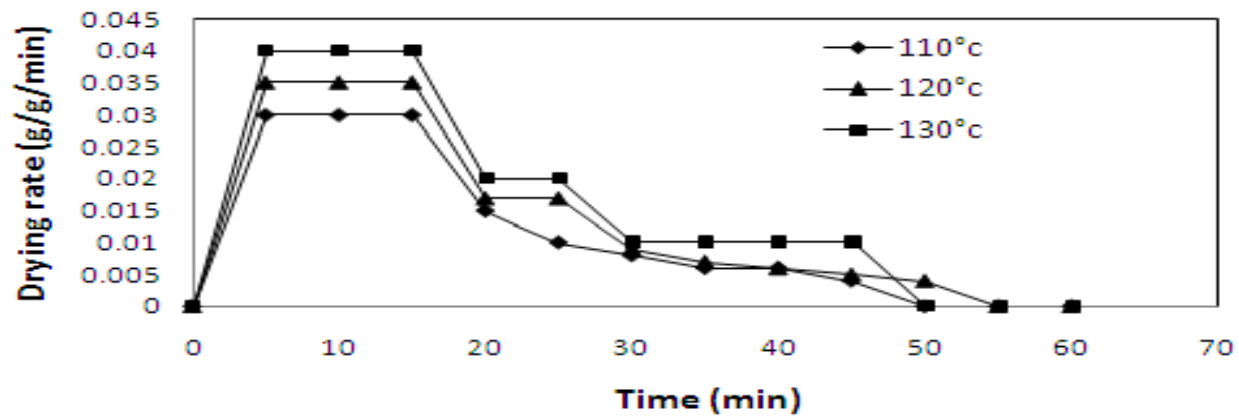

Figure 3 Drying rate versus time for corn at varying temperatures.

Table 4 Experimental values for drying rate of Ogbono at varying temperatures.

\begin{tabular}{|l|l|l|l|}
\hline $\begin{array}{l}\text { Time } \\
(\min )\end{array}$ & $\begin{array}{l}\text { Drying rate } \\
\min )\left(110^{\circ} \mathrm{C}\right)\end{array}$ & $\begin{array}{l}\text { Drying rate }(\mathrm{g} / \mathrm{g} / \mathrm{min}) \\
\left(120^{\circ} \mathrm{C}\right)\end{array}$ & $\begin{array}{l}\text { Drying rate }(\mathrm{g} / \mathrm{g} / \mathrm{min}) \\
\left(130^{\circ} \mathrm{C}\right)\end{array}$ \\
\hline 0 & 0 & 0 & 0 \\
\hline 5 & 0.08 & 0.09 & 0.1 \\
\hline 10 & 0.08 & 0.09 & 0.1 \\
\hline 15 & 0.08 & 0.09 & 0.1 \\
\hline 20 & 0.06 & 0.065 & 0.07 \\
\hline 25 & 0.05 & 0.045 & 0.04 \\
\hline 30 & 0.03 & 0.025 & 0.02 \\
\hline 35 & 0.01 & 0.015 & 0.02 \\
\hline 40 & 0.01 & 0.008 & 0 \\
\hline 45 & 0.01 & 0.006 & 0 \\
\hline 50 & 0.01 & 0.004 & 0 \\
\hline 55 & 0 & 0.002 & 0 \\
\hline 60 & 0 & 0.001 & 0 \\
\hline
\end{tabular}

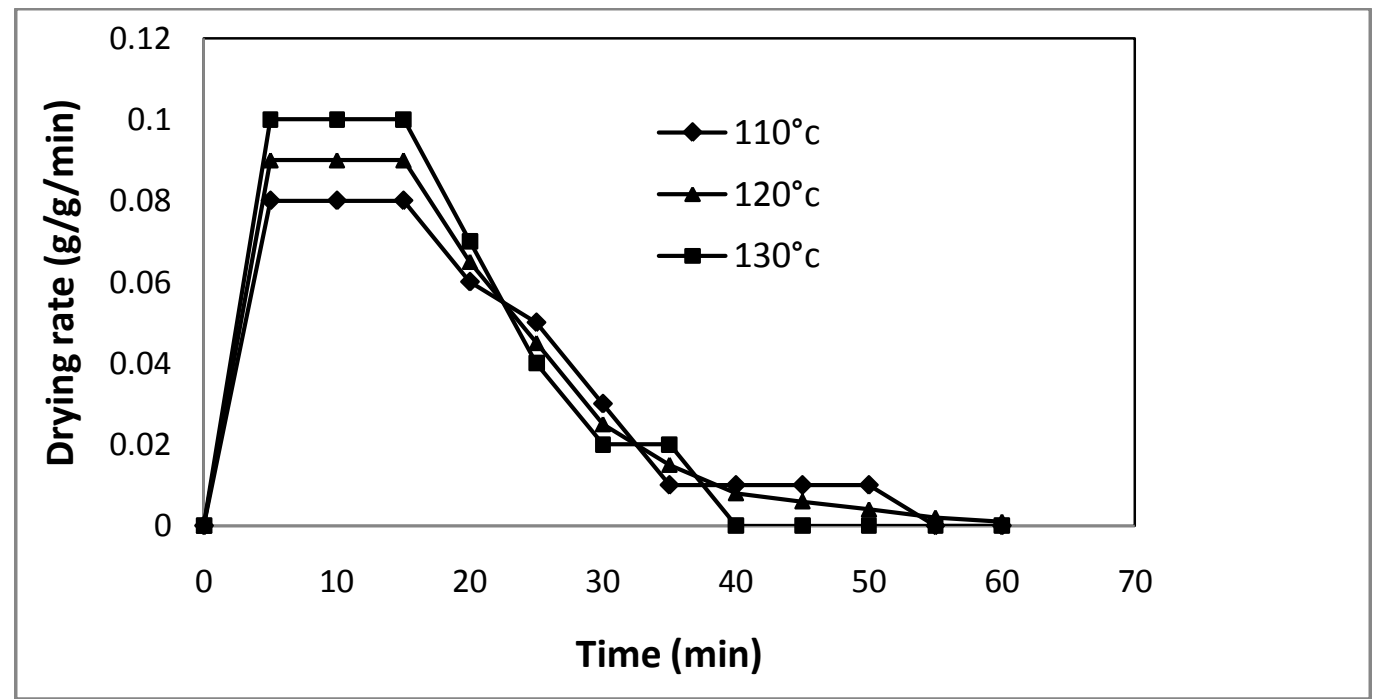

Figure 4 Drying rate versus time for ogbono at varying temperatures.

\subsection{PROXIMATE ANALYSIS}

This account for the nutritional value at the two temperatures studied, $110^{\circ} \mathrm{C}$ and $130^{\circ} \mathrm{C}$ of the dried and fresh corn and ogbono (See Tables 5 and 6). Ash and moisture content was reduced after drying. The protein and lipid (oil and fat), content increased at $110^{\circ} \mathrm{C}$ and $130^{\circ} \mathrm{C}$ but a lower fiber was observed at $130^{\circ} \mathrm{C}$. Comparing the two temperatures, the fiber that is good for old people also was higher at $110^{\circ} \mathrm{C}$ but carbohydrate was lower but showed higher carbohydrate at $130^{\circ} \mathrm{C}$. 
Table 5 Nutritional value for samples dried at $110^{\circ} \mathrm{C}$

\begin{tabular}{|l|l|l|l|l|l|l|l|}
\hline Sample Code & $\%$ Ash & $\%$ Moisture & $\%$ Protein & $\%$ Lipid & $\%$ Fibre & $\%$ Dry Matter & $\%$ Carbon-hydrate \\
\hline Dry corn & 8.675 & 58.724 & 9.940 & 3.78 & 2.80 & 41.276 & 76.80 \\
\hline Fresh corn & 10.925 & - & 8.850 & 1.56 & 3.76 & - & 74.90 \\
\hline Dried-Ogbono & 6.40 & 64.82 & 5.400 & 2.17 & 2.40 & 35.18 & 83.63 \\
\hline Fresh ogbono & 10.01 & - & 4.20 & 0.98 & 3.21 & - & 81.60 \\
\hline
\end{tabular}

Table 6. Nutritional value for samples dried at $130^{\circ} \mathrm{C}$

\begin{tabular}{|l|l|l|l|l|l|l|l|}
\hline Sample Code & $\%$ Ash & \% Moisture & $\%$ Protein & $\%$ Lipid & \% Fibre & $\begin{array}{l}\text { \%Dry } \\
\text { Matter }\end{array}$ & $\begin{array}{l}\text { Carbon- } \\
\text { hydrate }\end{array}$ \\
\hline Dry corn & 5.451 & 64.420 & 8.740 & 3.90 & 2.35 & 35.58 & 82.559 \\
\hline Fresh corn & 7.504 & - & 5.860 & 1.85 & 3.48 & - & 81.316 \\
\hline $\begin{array}{l}\text { Dried- } \\
\text { Ogbono }\end{array}$ & 3.720 & 37.24 & 4.240 & 2.34 & 2.10 & 62.76 & 87.60 \\
\hline Fresh ogbono & 6.250 & - & 2.09 & 1.09 & 3.50 & - & 87.07 \\
\hline
\end{tabular}

Table 7 Mineral Analysis at $110^{\circ} \mathrm{C}$

\begin{tabular}{|l|l|l|l|l|l|l|l|}
\hline Sample code & $\mathrm{Ca}$ & $\mathrm{Mg}$ & $\mathrm{Na}$ & $\mathrm{K}$ & $\mathrm{P}$ & $\mathrm{Mn}$ & $\mathrm{Fe}$ \\
\hline Dry corn & 0.2 & 0.065 & 0.017 & 0.180 & 0.28 & 0.060 & 0.002 \\
\hline Fresh corn & 0.28 & 0.090 & 0.062 & 0.242 & 0.35 & 0.081 & 0.003 \\
\hline Dry Ogbono & 0.34 & 0.081 & 0.025 & 0.25 & 0.15 & 0.068 & 0.010 \\
\hline
\end{tabular}

\section{CONCLUSION}

Storage of agro products without deterioration is a great challenge because of the moisture content, especially in developing countries. Stable agro products, corn and ogbono falls under this category and one way to profer solution is drying. Moisture content studied at $130^{\circ} \mathrm{C}$ for $95 \mathrm{~min}$ on corn and ogbono $0.1 \mathrm{~g}$ and $0.8 \mathrm{~g}$ respectively. The drying rate was also higher than compared to the temperature at $110^{\circ} \mathrm{C}$ and $120^{\circ} \mathrm{C}$. However, the drying temperature at $110^{\circ} \mathrm{C}$ was the most favourable condition evaluated, yielding uniformly dried corn and ogbono, retained best colour and did not scorch. The proximate analysis showed favourable nutritional values; the protein, lipid and fiber dried at $110^{\circ} \mathrm{C}$ were higher than that at $130^{\circ} \mathrm{C}$ with lower carbohydrate, suitable for both young and elderly. At $110^{\circ} \mathrm{C}$ and $120^{\circ} \mathrm{C}$ it can still be stored without deterioration but the longitivity will not be like that of $130^{\circ} \mathrm{C}$. The analysis showed traces of minerals such as $\mathrm{Ca}, \mathrm{Mn}, \mathrm{K}, \mathrm{Na}, \mathrm{P}$ and $\mathrm{Mg}$ in both corn and ogbono

\section{ACKNOWLEDGEMENT}

The authors are grateful to the department of chemistry, Niger Delta University, PMB 071. Wilberforce Island. Bayelsa State. Nigeria, where both the experimental determination of proximate and mineral analysis were conducted.

\section{REFERENCES}

[1]. I. Dincer 'Sun drying of sultan grapes"'. Drying Technology,14: 1996. pp.1827-1838

[2]. J. Waewsak, S. Chindaruksa and C Punlek, 'A mathematical modeling study of hot air drying for some agricultural products". Thammasat International Journal of Science and Technology. Vol 11: 2006 pp 14-20

[3]. J.Y. Seyed, R.G, Moreira, and R. Yamseangsung, "Superheated steam impingement drying of tortilla chip". Drying Technology. NO 17 1999. pp 191-213.

[4]. S.E. Agarry and C.N. Owabor "Modelling of the drying kinetics of Banana under natural convection and forced air drying" Journal of the Nigerian Society of Chemical Engineeers Vol. 27, No1 2012. Pp 103-115.

[5]. M.S. Hatamipour, H. hadji Kazemi, A. Nooralivand and Nozarpoor "Drying characteristics of six varities of sweet potatoes in different dryers". Trans IChemE Part C. Food and Bioproduct processing. Vol. 85 (C3) 2007 pp 171-177.

[6]. W. Mulatu. "Solar drying of fruits and windows of opportunities in Ethiopia" African Journal of food Science . Vol. 4 (13) 2010. Pp 790-902.

[7]. D. Setiady, C. Clary, F. Younce and B.A. Rasco "Optimizing drying conditions for microwave -vacuum (MIVAC): Drying of Russet Potatoes (Salanum tuberosum)" Drying Technology. VOl. 25 2007. 1479-1685.

[8]. A. Midilli, "Determination of drying behavior and conditions in a solar drying system". International Journal of Energy Research, NO 25: 2001. pp 715-725.

[9]. Hustrulid and Flikke. . Experimental drying of corn kernels in a thin layer”. NO 451959 pp 226-240.

[10]. C.E. Lupano and M.C. Anon, "Denaturation of wheat germ proteins during drying". Cereal Chem. NO 63: 1986. pp 259-263.

[11]. D. Elustondo, M. Elustondo, M.J. Urbicain "Mathematical modeling of moisture evaporation from food stuffs exposed to sub atmosphere pressure superheated steam". Journal of Food Eng. NO 492001 pp 15-24.

[12]. Stanislaw; DRYING, "Thermo physical properties of grains and oilseeds". 1988 pp 156-157. 